\title{
Nitrogen Oxide Abatement by Distributed Fuel Addition Contract DE-AC22-87PC79850
}

Quarterly Report No. 3

$\mathrm{DOE} / \mathrm{PC} / 79850--3$

DE92 005205

for Period

February 1,1988 through April 30, 1988

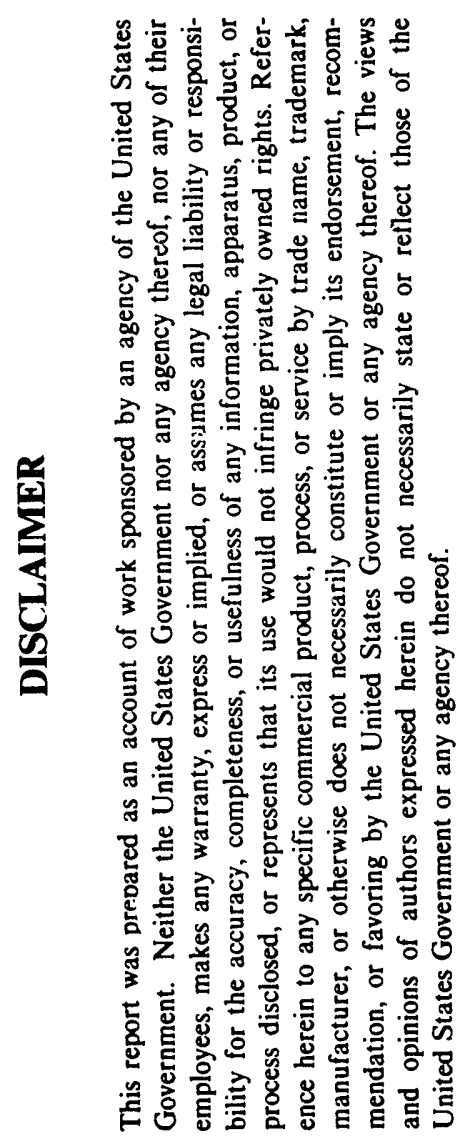

\author{
Prepared by \\ J.O.L.Wendt and J. Meraab \\ Department of Chemical Engineering \\ University of Arizona \\ Tucson, Arizona 85721 \\ Submitted to \\ Diane Revay Madden, Project Officer \\ Environmental Control Technology Division \\ Pittsburgh Energy Technology Center \\ Department of Energy
}

June 27,1988

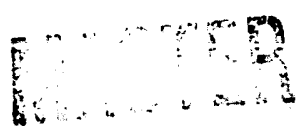


This research is directed towards the development of engineering guidelines that define the application of distributed fuel addition as a technique for NOx abatement. It is expected that multiple fuel and air addition in the post-flame of a combustion process will increase free radical concentrations which destroy nitrogenous species and thus help them decay toward their equilibrium concentrations, which can be very low in that region of the combustor.

Screening experiments were conducted on a laboratory scale downfired combustor. The objective was to compare NOx emissions arising from various combustion configurations, including fuel and/or air staging. Although the primary focus of this research is on NO control, a secondary effort was directed towards the measurement of $\mathrm{N} 20$ emissions from various coal combustion processes. $\mathrm{N} 20$ has been identified as a trace gas responsible for stratospheric ozone depletion, and has been hypothesized to arise from combustion processes, in amounts roughly proportional to NO emissions.

Results presented in this report showed that the ratio N20/NO was far from constant. The introduction of secondary air into a combustion process was accompanied an increase in $\mathrm{N} 2 \mathrm{O}$ emissions. The measured $\mathrm{N} 2 \mathrm{O}$ was always less than $10 \mathrm{ppm}$ even under the most favorable combustion conditions. Reburning with premixed fuel and air mixtures was not effective in reducing NO emissions. 


\section{INIRODUCTION}

There have been considerable advances in control technology to reduce emissions of nitrogen oxides from stationary sources such as coal combustion processes. The use of fuel as a reducing agent to remove NOx from the combustion products have been shown to be an effective method in NOx emission control. This technology is referred to as "reburning" because the combustion products are reburned by introducing additional fuel downstream of the primary combustion zone. The variables which affect the reduction of NOx by reburning have been widely investigated by various researchers $(1,3,4,5)$. The following is a review of the effect of some of these variables on the reburning process.

The stoichiometric ratio in the primary zone has iittle effect on reburning effectiveness provided that sufficient oxygen or oxidizing radicals reach the reburn zone to break down the reburn fuel and generate hydrocarbon radical species. The $\mathrm{CH}$ radical is formed as a minor byproduct. It is the $\mathrm{CH}$ radical concentration which is the determining factor in reducing NO emissions according to the following path:

$$
\begin{aligned}
& \mathrm{CH}+\mathrm{NO}-.>\mathrm{HCN}+\mathrm{O} \\
& \mathrm{HCN}-->\mathrm{NCO}-->>\mathrm{NH} \ldots>\mathrm{N} \\
& \mathrm{N}+\mathrm{NO}-.>\mathrm{N} 2+\mathrm{O}
\end{aligned}
$$

According to this theory, the key limitation to reburning is the availability of the $\mathrm{CH}$ radical. There may, however, be other, equally important, kinetic routes for the conversion of NO to N2.

In the reburn zone, there is an interconversion of nitrogen species among the different fixed nitrogen compounds namely, NO, HCN and $\mathrm{NH} 3$. Such a tradeoff would mask the actual effectiveness of reburning if only No concentrations were monitored. The addition of burnout air would oxidize all the remaining fuel and the total fuel nitrogen ( $\mathrm{NO}+\mathrm{HCN}+\mathrm{NH} 3$ ) would be converted partially to NO and partially to N2.

It has been found that the reburning process is more effective at higher levels of NO in the primary zone. Miyamae et al. (4) proposed that the ratio of hydrocarbon concentration into the reburning zone to that of the primary zone concentration of NO was an important variable in determining reburning effectiveness. An optimun reburn zone stoichiometric ratio of about 0.9 has been found by several researchers $(1,3,4,5)$.

Reburning is most effective when the reburn fuel is introduced at the hottest location or as close to the primary flame as possible while leaving adequate residence time for the primary fuel to be completely consumed. Also, the burnout air should be introduced as late as possible to allow adequate time for the decomposition of the nitrogenous species.

Oxygen injected with the reburn fuel may cause direct consumption of the fuel and reduce the $\mathrm{CH}$ radical generation. Thus, means which slow the consumption of reburn fuel, such as slow mixing, might enhance the reburning action. Slow mixing is favored by low inlet velocities of the rebuming fuel streauls. Times for combustion if the reburn fuel and generation of $\mathrm{CH}$ 
radicals can be also extended by distributing the reburning zone down the combustor through multiple fuel injection ports.

The proposed experimental plan and the experimental setup were described in a previous report (6). Preliminary experiments, described there, showed that the location of the reburn zone was less relevant at longer residence times al. I lower temperatures. Significant reductions in NO due to rebuming could also be achieved with the reburn zone under overall fuel lean conditions. 


\section{N2O MEASUREMENTS}

In the previous report (7), the significance of $\mathrm{N} 20$ emissions to the environment and some of the theories behind its formation were discussed. A reliable and reproducible analytical procedure was developed for on line sampling and analysis of $\mathrm{N} 20$. The procedure was later modified to employ an electron capture detection temperature of $250 \mathrm{C}$. The presence of an electronegative compound such as oxygen would cause rapid deterioration in ECD performance. Employing a lower detection temperature would reduce the damaging effect caused by the presence of oxygen in the sample (2). The sensitivity of the ECD at $250 \mathrm{C}$ was reduced by a factor of about 6 compared to that at $350 \mathrm{C}$. Nevertheless, $\mathrm{N} 20$ measurements as low as $0.3 \mathrm{ppm}$ were still possible. Table 1 lists the instrumental parameters that are used in N2O measurements. Figures 1 and 2 show the effect of variable 02 and $\mathrm{CO} 2$ concentrations respectively on ECD measurements of $\mathrm{N} 20$ and Figure 3 shows the effect of water vapor. These compounds show Little on no interference with $\mathrm{N} 20$ response. Figure 4 shows sample chromatograms at two different ECD temperatures.

It should be noted that, throughout this work, samples were withdrawn through a water quenched, water cooled sample probe. The water was then removed via a refrigerated knockout pot, and the sample enalyzed chromatographically in-line. Many other researchers have analyzed samples which have been stored in sample bombs, with or without the water of combustion present. 


\section{EXPERTMENTAZ RESULTS}

Several experiments were performed under various fuel and/or air staging conditions. The results are shown in Table 2. To correct for dilution effects due to changes in stoichiometry and due to the addition of reburning fuel and/or air, all measured NO and N2O concentrations were multiplied by the ratio of total calculated dry moles of flue gas to that of the total theoretical dry moles corresponding to a stoichiometric ratio of unity with respect to the primary fuel. This quantity is then proportional to the fraction of coal nitrogen finally converted to NO in the exhaust, if the amount of Thermal No can be neglected.

Figure 5 shows NO and N2O exhaust concentrations at different stoichiometric ratios for two different types of coal, a Utah Bitumincus coal and a N. Dakota Beulah Lignite. NO emissions are as expected, but N2O emissions are very low and less than $2 \mathrm{ppm}$. Figures 6 and 7 compare NO emissions for various combustion configurations, including air staging and reburning. It is obvious that reburning with a premixed fuel and air combination is not very effective in reducing NOx levels and may result in higher NO emissions. As discussed earlier, this may be due to direct consumption of the fuel and consequent reduction in free radical generation. Some NO was formed at the point of final bumout air addition.

Figures $8,9,10$ and 11 show NO and N2O profiles as a function of residence time at different stoichiometric ratios. Low concentration levels of $\mathrm{N} 2 \mathrm{O}$ (less than $2 \mathrm{ppm}$ ) were obtained.

Figure 12 shows NO and N2O profiles for a typical reburning experiment. Reburn fuel was added at $0.68 \mathrm{~s}$ (denoted by the first vertical dashed line) and burnout air at $1.27 \mathrm{~s}$ (denoted by the second vertical dashed line). Reburning lowered the NO profile by 608 . N20 concentrations increased upon the addition of burnout air.

Figures 13, 14 and 15 show typical air staging combustion experiments. The addition of staged air resulted in a decrease in NO concentrations and an increase in $\mathrm{N} 2 \mathrm{O}$ concentrations, although the latter were still small (less than $9 \mathrm{ppm}$ ). The increase in $\mathrm{N} 20$ concentrations might be due to the increase in HCN formation from char nitrogen. HCN is formed in the post flame gas phase from char nitrogen devolatilization and is a precursor to N2O formation according to the following path as proposed by Kramlich (2):

$$
\begin{aligned}
& \mathrm{HCN}+\mathrm{O}--\rightarrow \mathrm{NCO}+\mathrm{H} \\
& \mathrm{NCO}+\mathrm{NO}--\rightarrow>\mathrm{N} 2 \mathrm{O}+\mathrm{CO} \\
& \mathrm{NCO}--\rightarrow \mathrm{NHi}-\rightarrow>\mathrm{N} 2 \mathrm{O}
\end{aligned}
$$

However, the $\mathrm{N} 20$ values obtained were far lower than anticipated. The temperature was kept in the 1150 - $1500 \mathrm{~K}$ range which is favorable for N2O formation (2).

Figures 16, 17 and 18 show results of reburning experiments in which the reburn fuel was a premixed fuel and air combination. It appears that this type of reburning is not effective in No reduction. The addition of air also resulted in an increase in N2O emissions. Possible reasons for this 
Several coal combustion schemes were tested and temporal profiles of NO and $\mathrm{N} 2 \mathrm{O}$ concentrations were compared. For rebuming to be effective, the consumption of the reburn fuel must be slowed down as much as possible. Consequently, reburn fuels would not be as effective when premixed with an oxidant. Reburning might be made more effective if the addition of reburn fuel were to be distributed down the combustor.

The N2O concentrations that were measured were too low (less than 10 ppm) for any reliable conclusions to be made concerning the effect of fuel and/or air staging on $\mathrm{N} 2 \mathrm{O}$ emissions. However, the introduction of air into a fuel rich zone was always accompanied by an increase in $\mathrm{N} 20$ emissions which might be caused by an increase in HCN formation from char nitrogen as discussed earlier.

The remaining screening studies will be conducted according to a statistically correct design of experiments. Response surface experimentation will be utilized for this purpose. This method allows the determination of an empirical relationship between the response and the controlled parameters in the experimental region of interest based on an experiment involving a minimal number of trials. 


\section{REFERENCES}

1. Greene, S.B., S. L. Chen, W. D. Clark, M. P. Heap, D. W. Pershing and W. R. Seeker, "Bench Scale Process Evaluation of Reburning and Sorbent 012 (1985).

2. Kramlich, J.C., R. K. Lyon and W. S. Lanier, "EPA/NOAA/NASA/USDA N2O Workshop, " U.S. EPA Report EPA-68-02-4247 (1987).

3. LaFond, J.F. and S. L. Chen, "An Investigation to Define the Physical/Chemical Constraints which Limit NOx Emission Reduction Achievable by Reburning," U.S. DOE Quarterly Report DE-AC22-86PC91025 (1987).

4. Miyamae, S., H. Idebe and K. Makino, "Evaluation of In-Furnace NOx Reduction," Proceedings of the 1985 Joint Symposium on Stationary Combustion
NOx Control,

5. Miyamae, S., T. Kiga, H. Ikebe and K. Suzuki, "Experimental Study on NOx Destruction Characteristics by Reburning of Pulverized Coal, " paper presented at the 1986 Fall Meeting of Western State Section/The Combustion
Institute, Tucson, Arizona (1986).

6. Wendt J.O.L. and J. Meraab, "Nitrogen Oxides Abatement by Distributed Fuel Addition," U.S. DOE 1st Quarterly Report DE-AC22-87PC79850
(1987).

7. Wendt J.O.L., and J. Meraab, "Nitrogen Oxides Abatement by Distributed Fuel Addition, " U.S. DOE 2nd Quarterly Report DE-AC22-87PC79850
(1988). 


\author{
Table 1. \\ UNIVERSTTY OF AREONA SAMPLING AND ANALYSTS TECHNIQUE FOR N2O
}

\title{
ON-LINE SAMPLING
}

Sample withdrawn through a water quenched, water cooled, stainless steel probe. Sample then passes through refrigerated knock-out pot, through filters and $\mathrm{CO}$ and $\mathrm{CO} 2 \mathrm{NDIR}$ analysers into GC sample loop."

\section{GC INSTRUMENTAL PARAMETERS}

Instrument: Shimadzu GC-8A

Column: Porapak Q. $12 \mathrm{ft} \times 1 / 8$ in stainless steel conditioned at $220 \mathrm{C}$

Oven Temperature: $35 \mathrm{C}$

Detector: Eectron Capture, Ni 63 at $250 \mathrm{C}$

Carrier Gas: Ar/5.22\%CH4 at $20 \mathrm{ml} / \mathrm{min}$

Sample: $1 \mathrm{mll}$ loop at 3 psig intake pressure

Calibration Gas:

$15.14 \%$ CO2, 1\% O2, 95 ppmv N2O, Balance N2

Carrier gas passes through a carrier gas purifier for $\mathrm{O} 2 / \mathrm{H} 2 \mathrm{O}$ removal and an indicating tube for $02 / \mathrm{H} 2 \mathrm{O}$ detection before entering the $G \mathrm{C}$

Recorder Input Voltage: $1 \mathrm{mV}$ 


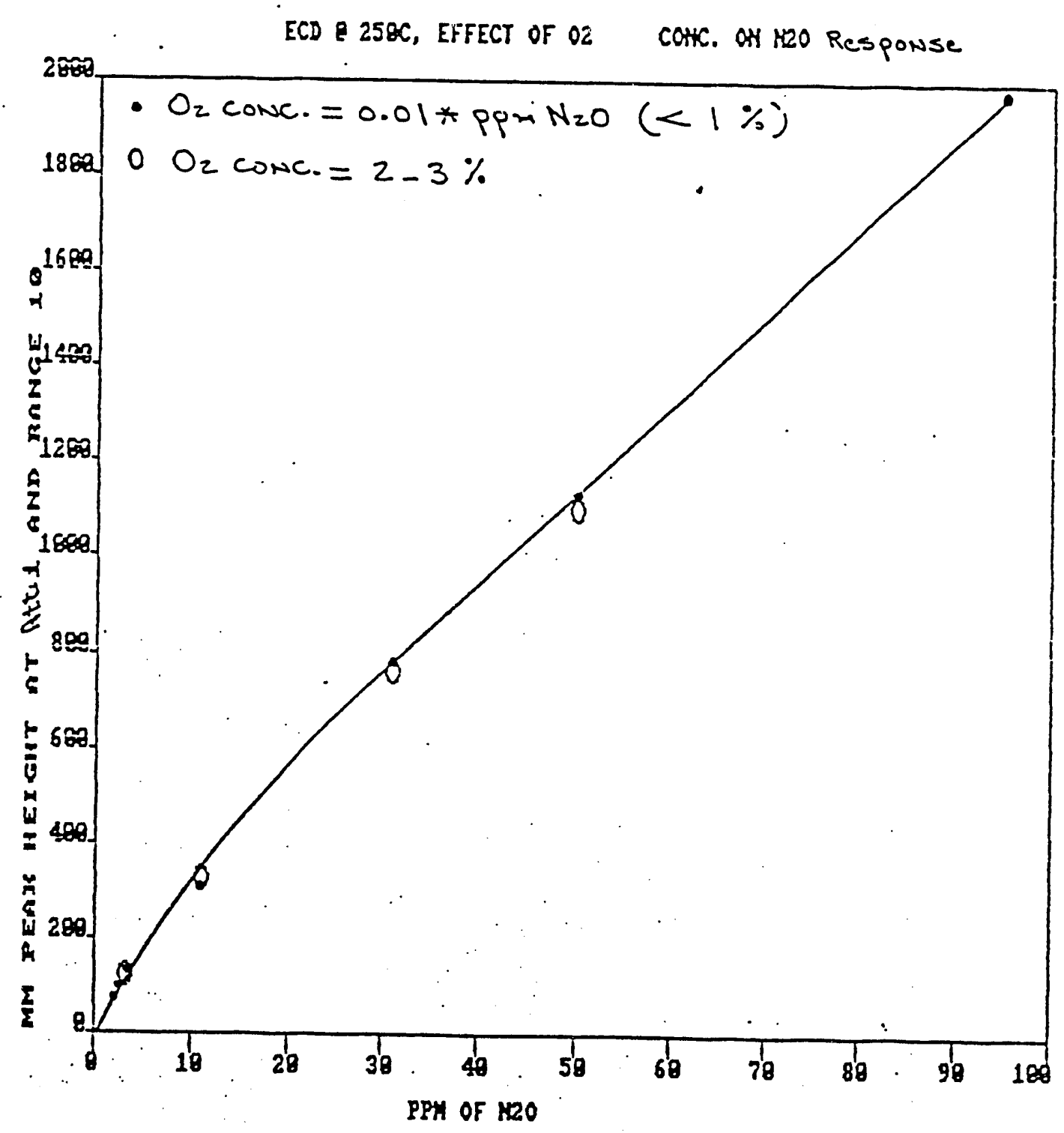

Figure 1. 


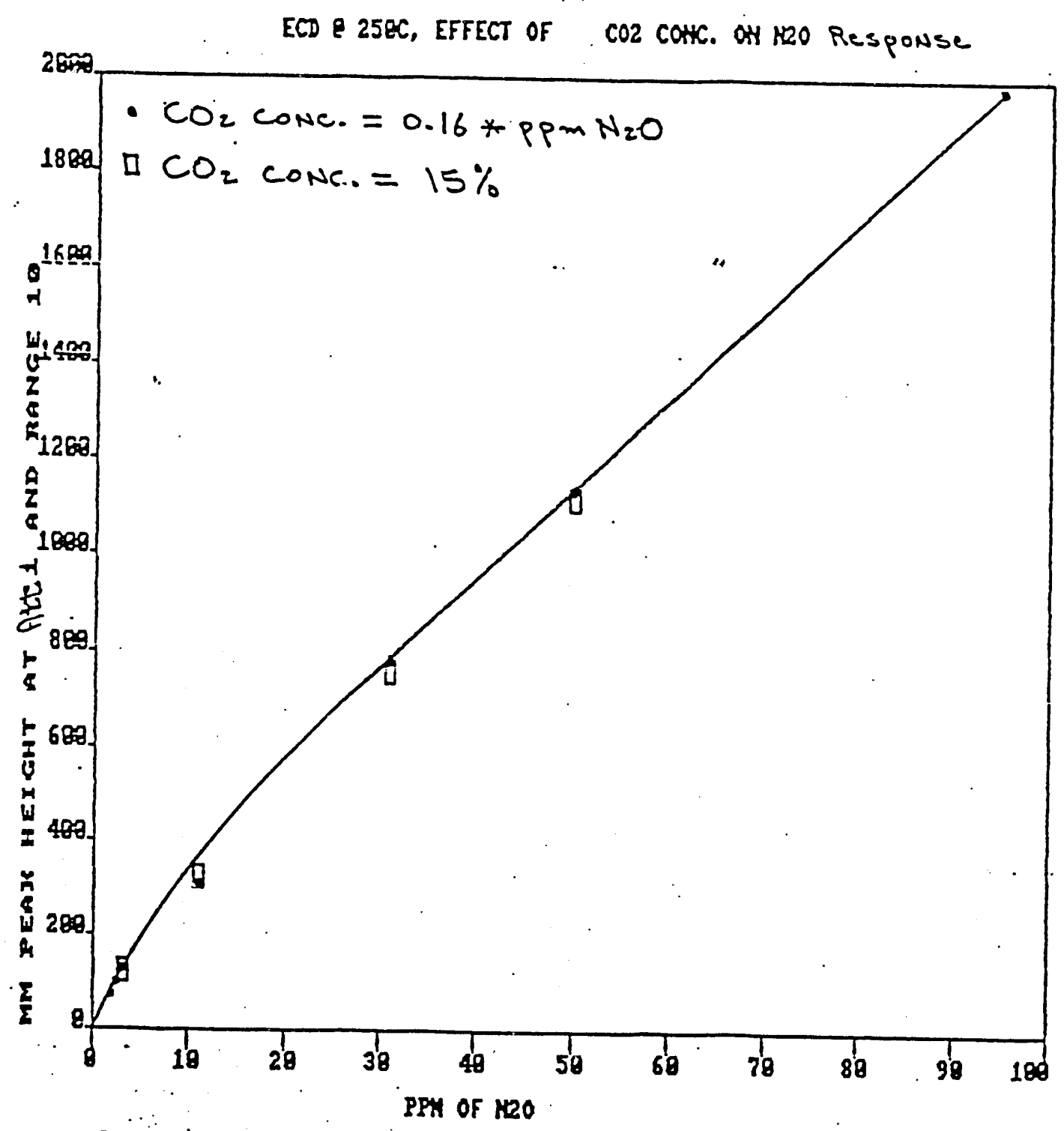

Figure 2. 
Effect of Water Vapor on N2O Response Detector e $350^{\circ} \mathrm{C}$

REO CALIBRATIOH

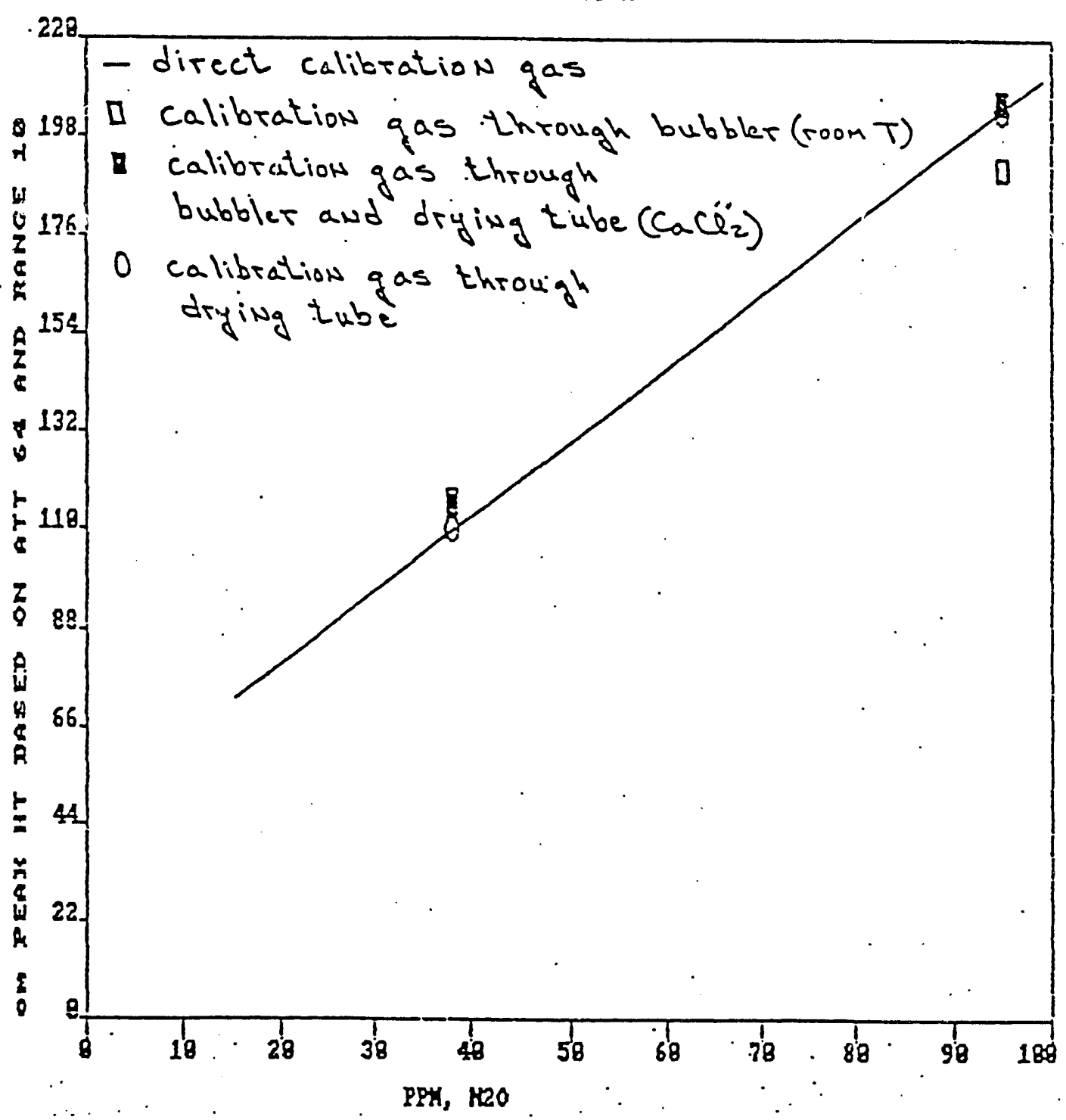

Figure 3. 


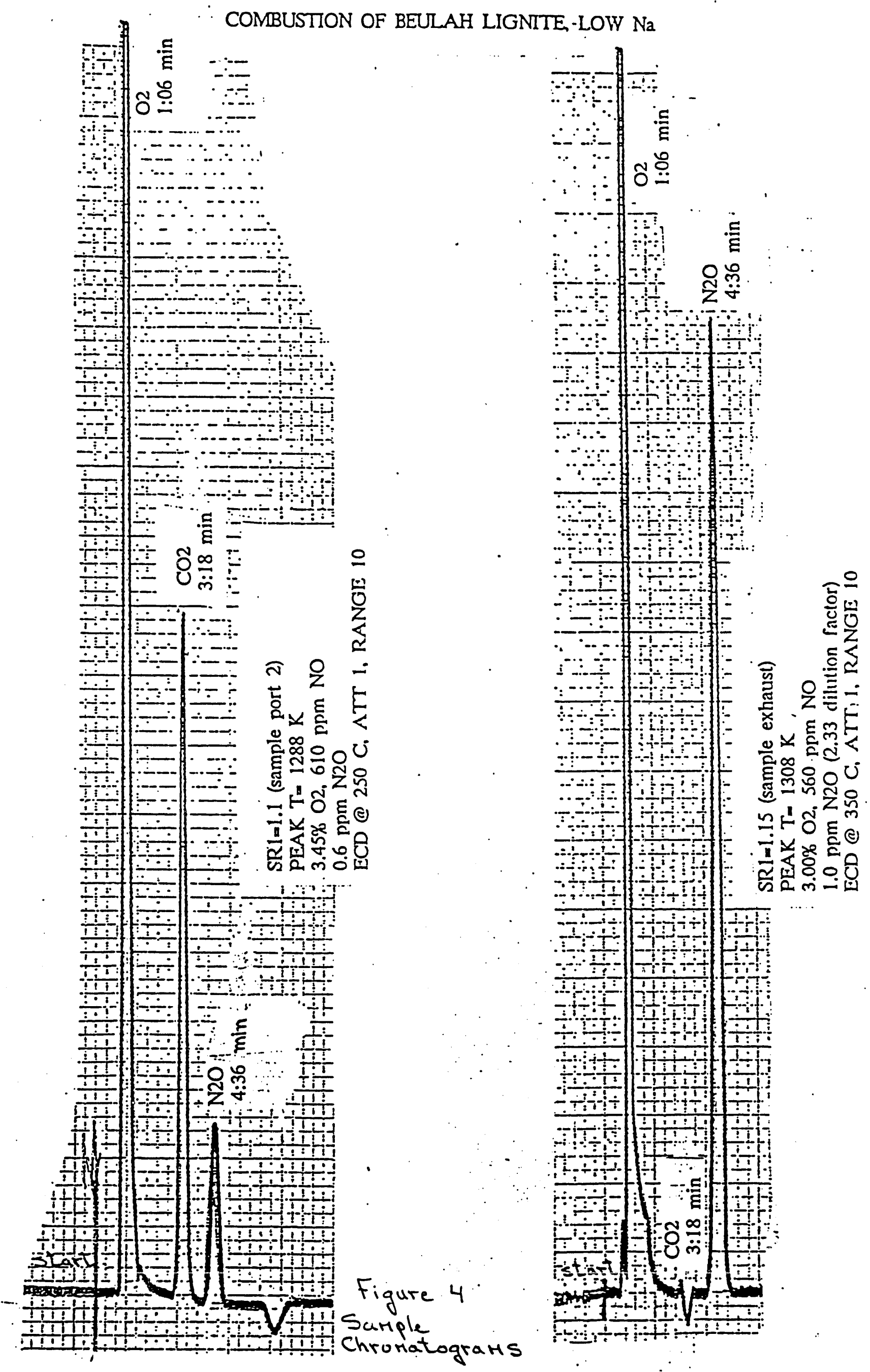




\section{TABLE 2.}

BEULAH LIGNITE, LOW $\mathrm{Na}$

CONC. VS. SRI (COAL FEED RATE $=2.08$ lb/hr) Data for Figures $5 b \xi 6$

$\begin{array}{rrrrrr}\text { SR1 } & \text { O2 } & \text { CO } & \text { CO2 } & \text { NO } & \text { N20 } \\ --- & \text { PCT } & \text { PCT } & \text { PCT } & \text { PPm } & \text { PPm } \\ 1.23 & --- & --- & --- & --- & --- \\ 1.19 & 3.45 & 0.5 & & 770 & 2.1 \\ 1.16 & 3 & 1.2 & 15.7 & 715 & 1.75 \\ 1.11 & 2.1 & 0.8 & 16.9 & 650 & 1.15 \\ 1.1 & 2 & 1.6 & 16.8 & 528 & 1.2 \\ 1.06 & 1.25 & 2 & 17 & 445 & 1.25 \\ 1.04 & 2.1 & 1.15 & 17.25 & 463 & 1.05 \\ 0.94 & 0.8 & 1.8 & 17.9 & 295 & 0.85 \\ 0.84 & 0.3 & 2.6 & 18 & 140 & 0.35\end{array}$

$\operatorname{SR} 1=1.11, \quad S R 2=0.86$

$S R 1=1.23, S R 2=1.10$

$162 \quad 1.9$

$S R 1=1.06, S R 2=0.90$

$S R 1=1.06, \quad S R 2=0.9, \quad S R 3=1.07$

438

1. 1

S.P1 $=1.06, \quad S R 2=1.07$ (GAS+AIR)

133

0.53

176

2. 9

$S R 1=1.06, \quad S R 2=1.07$ (DOUBLE CHARGE)

453

523

UTAH BITUMINOUS *2

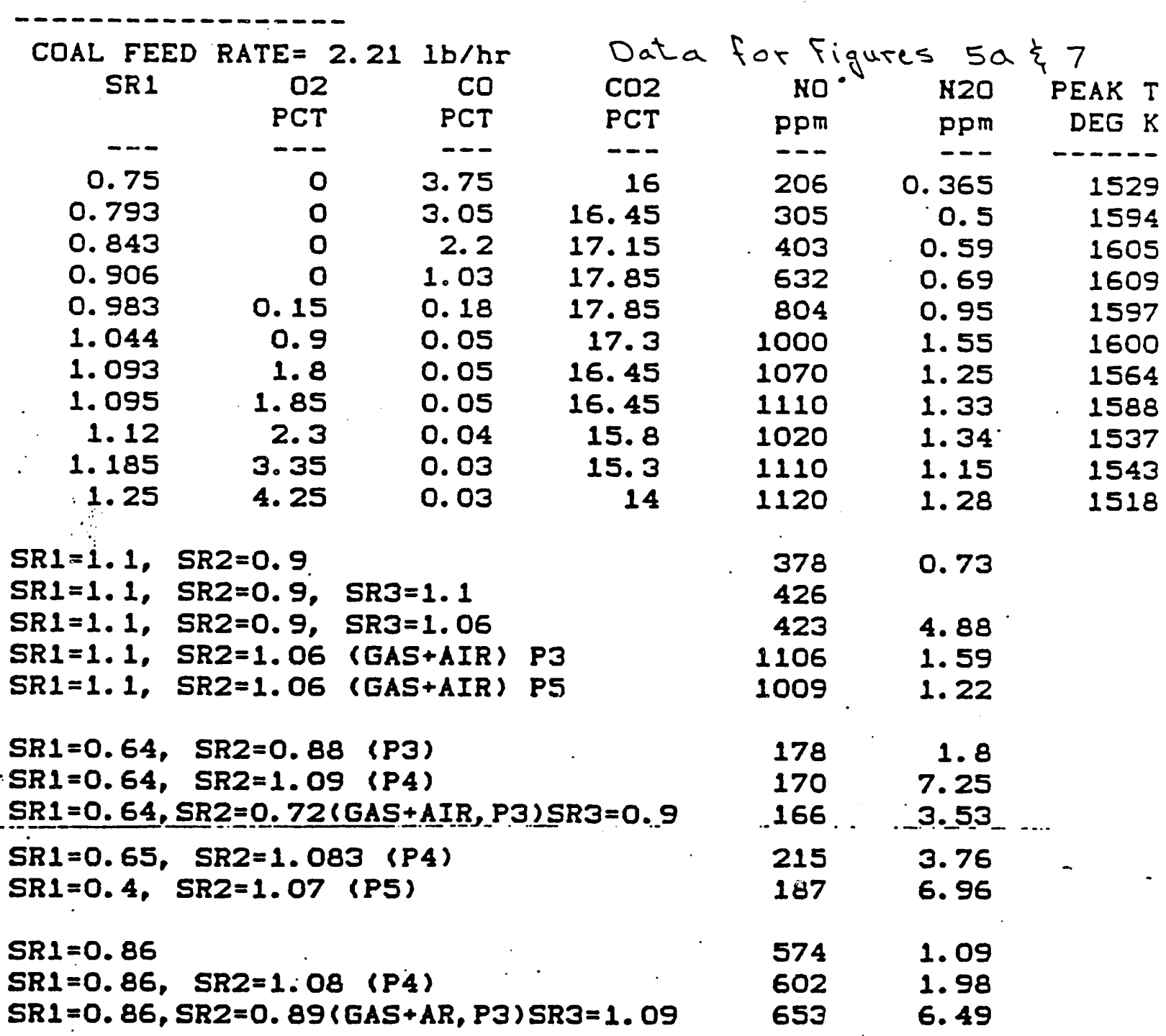


PORT PROFILES:

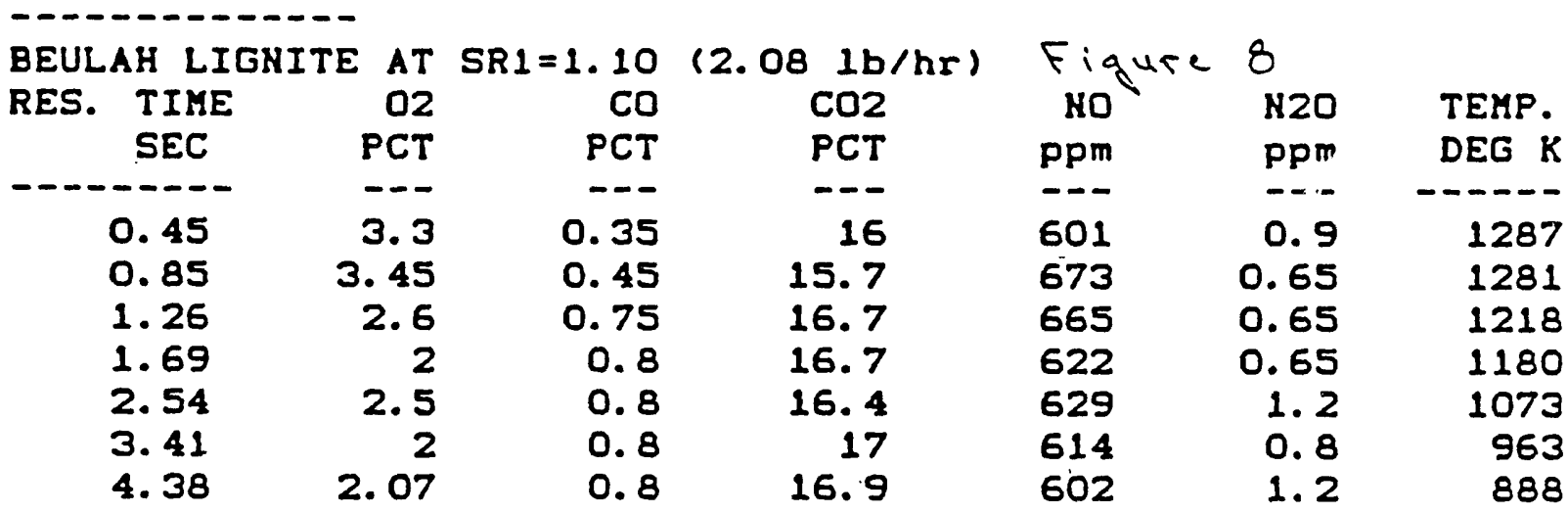

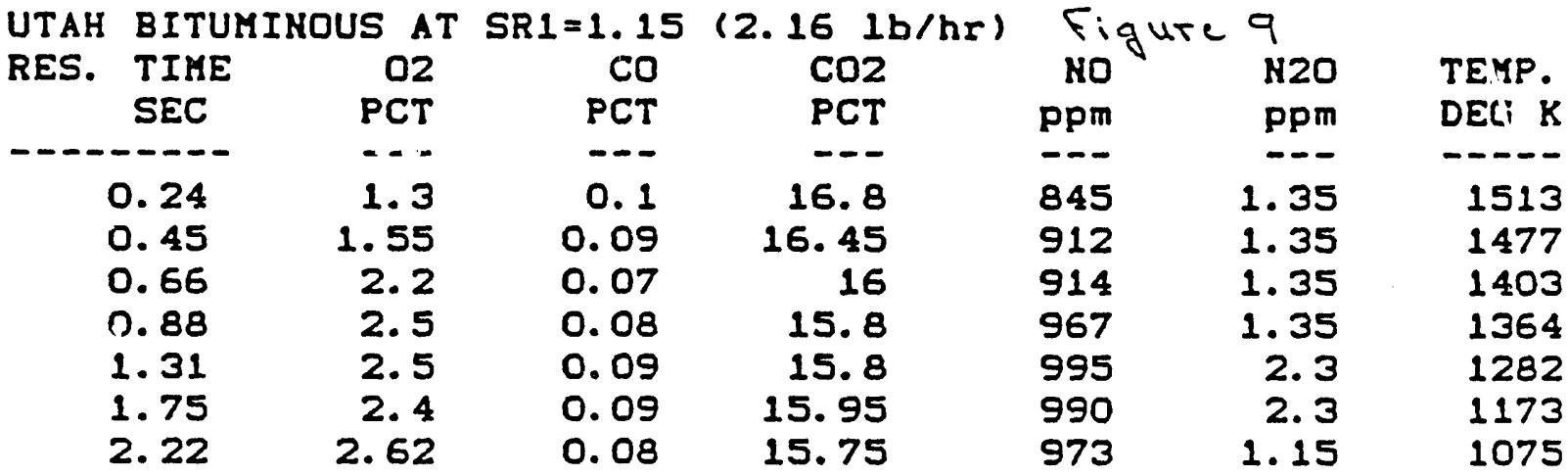

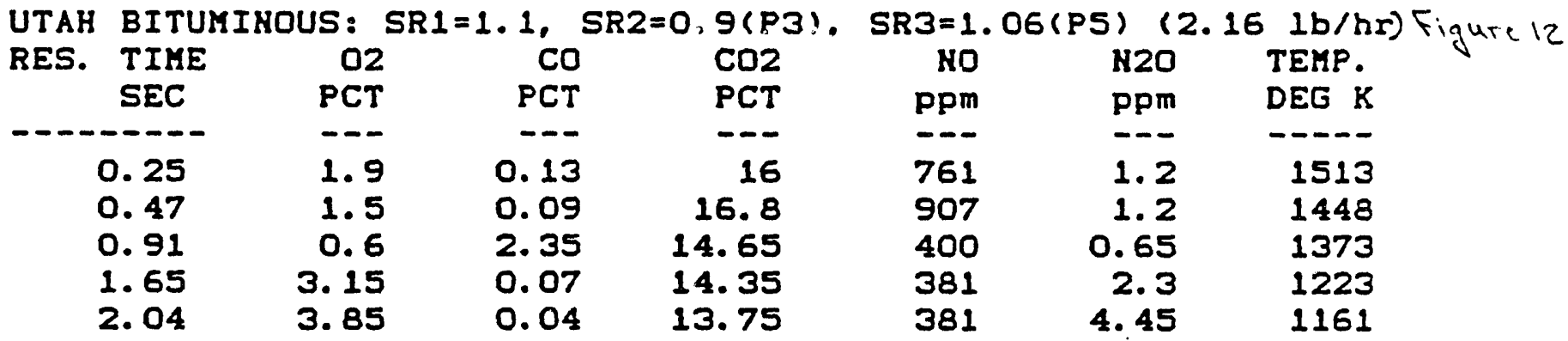

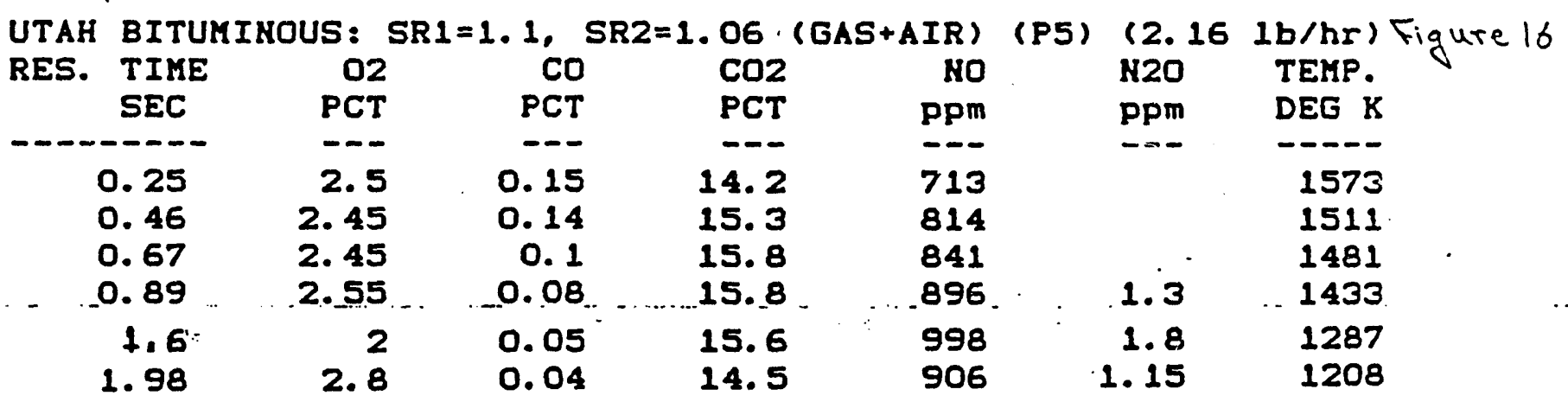




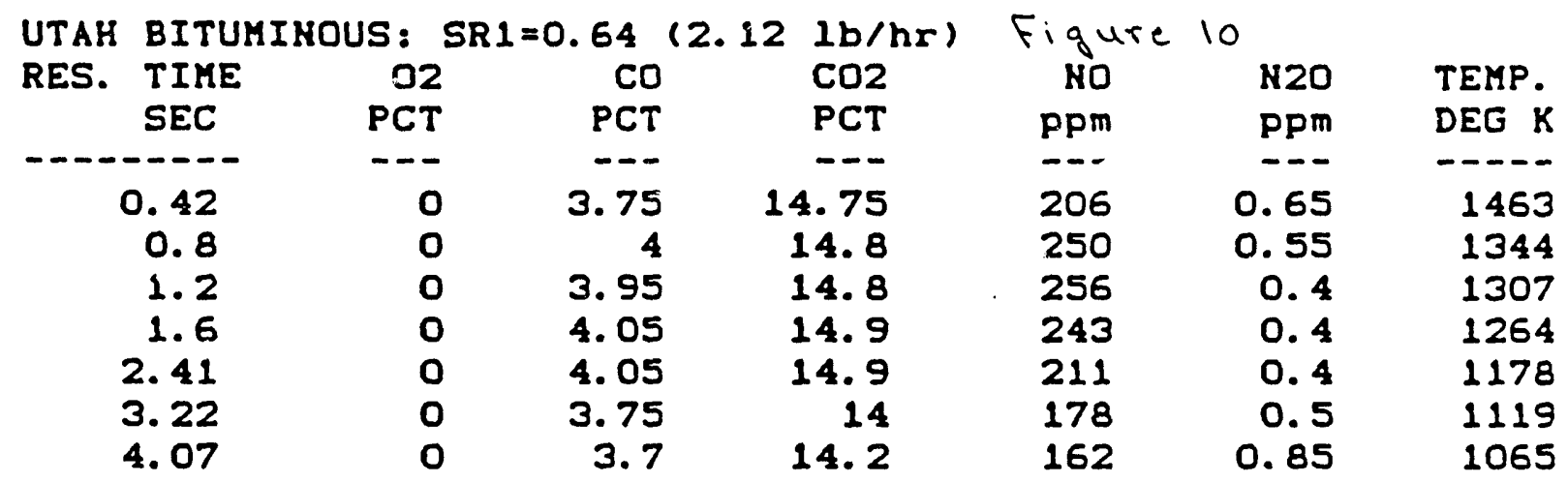

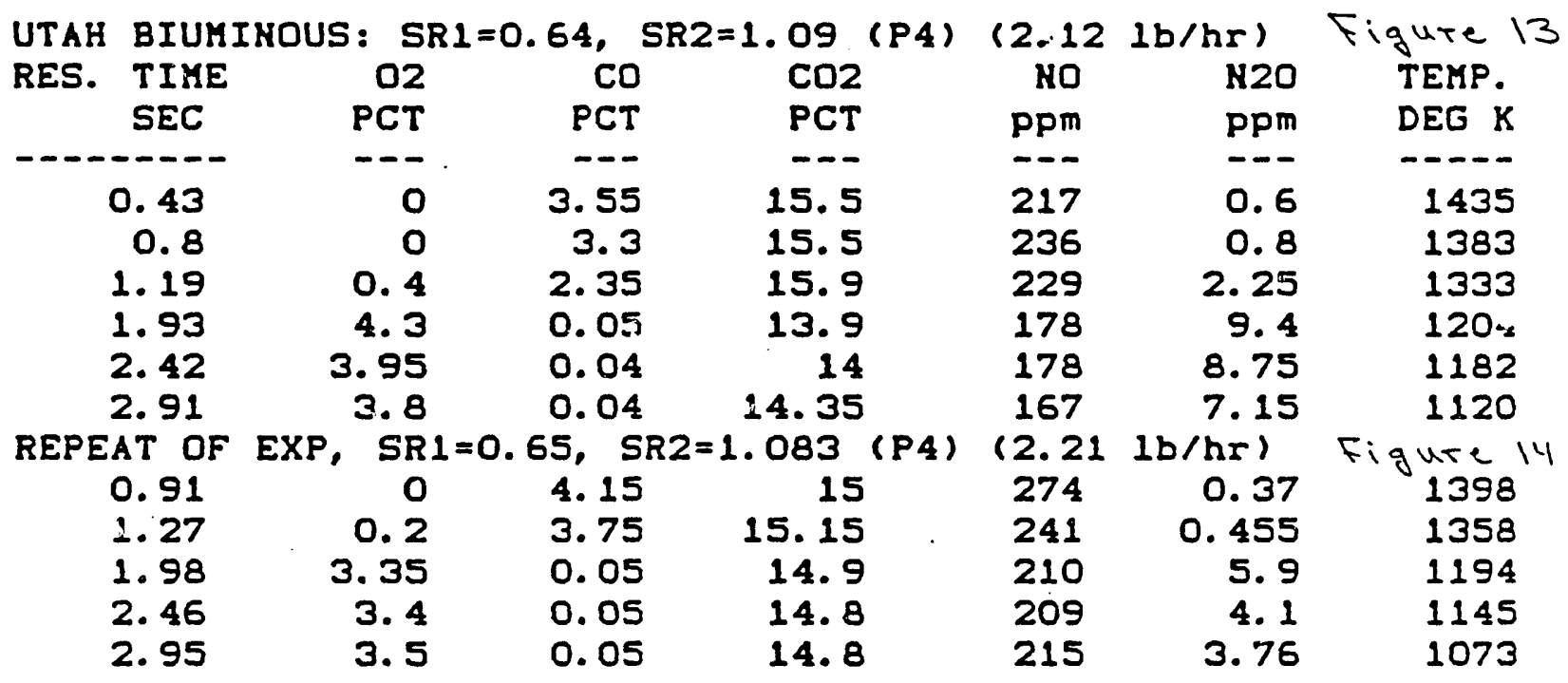

Figure 18

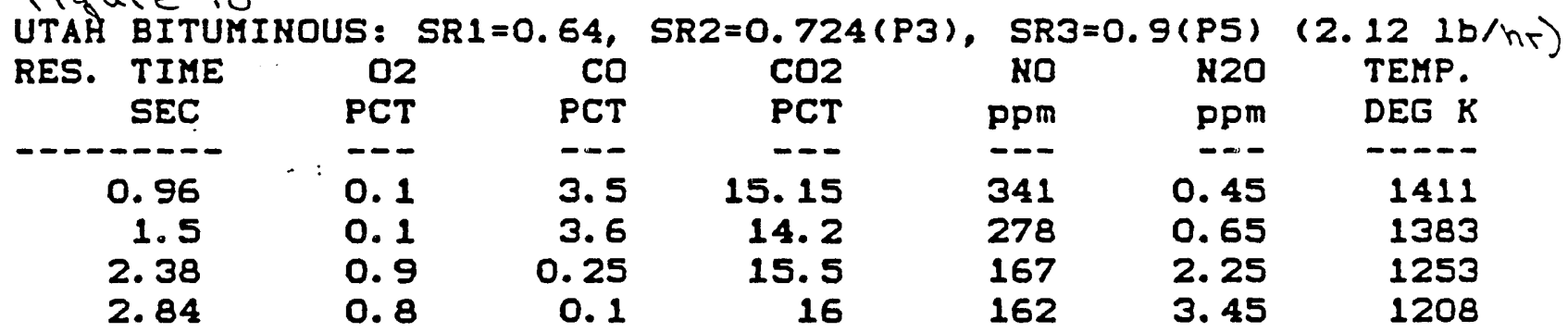

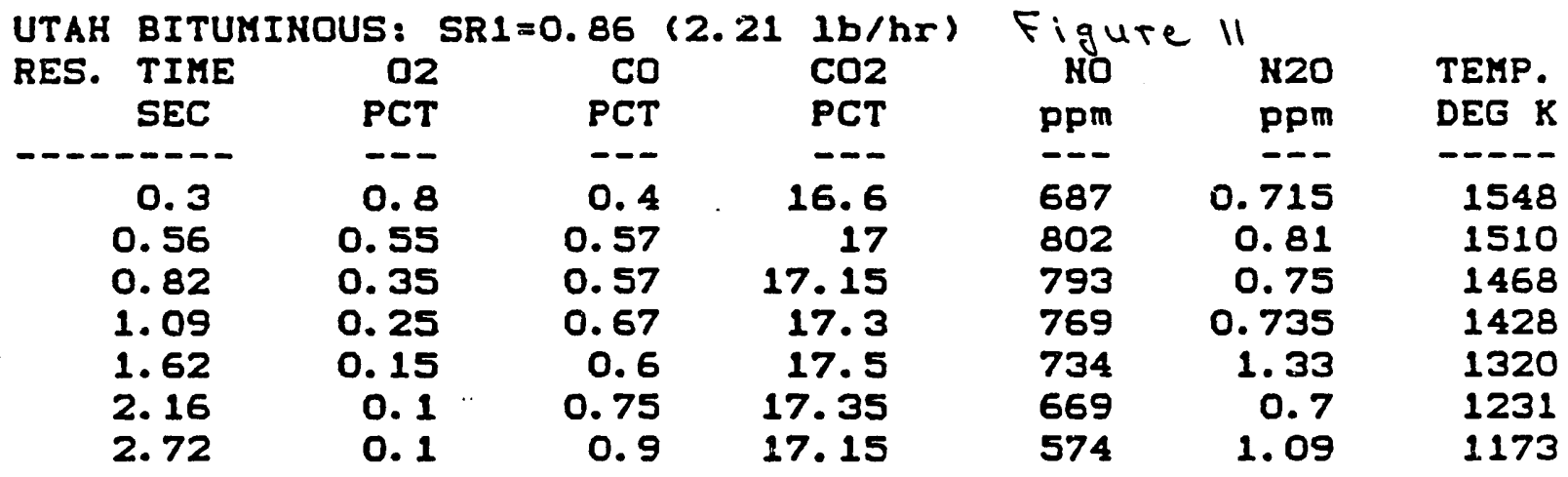




\begin{tabular}{|c|c|c|c|c|c|c|c|c|}
\hline UTAH & BITUI & US: & $=0.86$, & $S R 2=1.08$ & (P4) & (2.21 & $1 b / h)^{2}$ & $\therefore$ \\
\hline RES. & TIME & 02 & co & $\mathrm{CO2}$ & & No & N20 & TEMP. \\
\hline & SEC & PCT & PCT & PCT & & ppm & ppm & DEG $K$ \\
\hline & ---- & --- & -- & --- & & --- & $\because-$ & $-\cdots$ \\
\hline & 0.7 & & 0.35 & 16.6 & & 809 & 0.79 & 1451 \\
\hline & $\begin{array}{l}0.98 \\
1.68\end{array}$ & 4.2 & $\begin{array}{r}0.5 \\
0.04\end{array}$ & 16. 45 & & 745 & 0.905 & 1373 \\
\hline & 2. 13 & $\begin{array}{r}4.2 \\
3.75\end{array}$ & 0.04 & 14.05 & & 594 & 3.09 & 1238 \\
\hline & 2.59 & 3.6 & 0.04 & 14.35 & & $\begin{array}{l}637 \\
602\end{array}$ & $\begin{array}{l}1.83 \\
1.98\end{array}$ & $\begin{array}{l}1228 \\
1153\end{array}$ \\
\hline
\end{tabular}

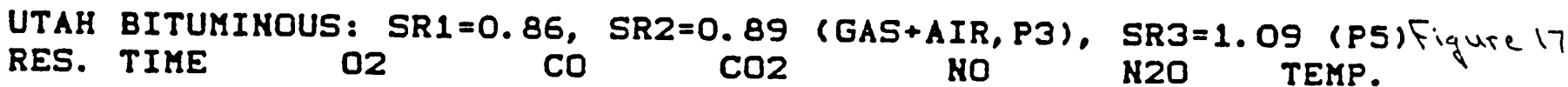
SEC

0.69

1. 12

1.83

2. 22

$$
\text { PCT }
$$

---

0.5

0.55

3.85

4. 4
PCT

$--$

0.4

0.08

0.04
PCT

---

17

16. 2

13. 3

13.1
NO

ppm

698

796

663

653 ppm

-.-

1.07

1

6. 49

NO

ppm

---

59

187
$\mathrm{CO} 2$

PCT

11.9

8.3

0.04

15.75

2. 8

3. 88

15. 75 

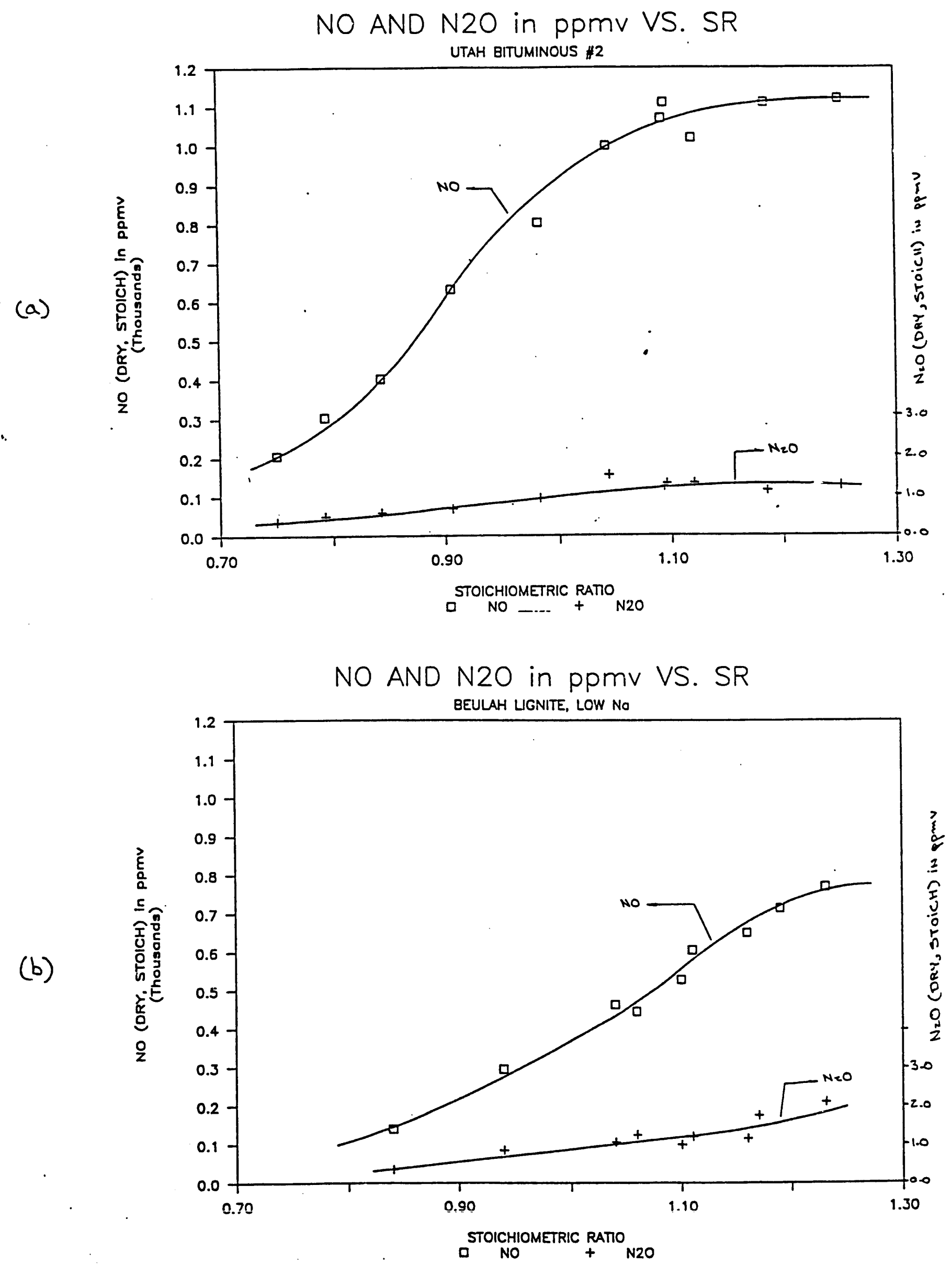

Figure 5. 
WO in Ppw vs. SRI/ BELLAH LIGNITE, LOH Ma

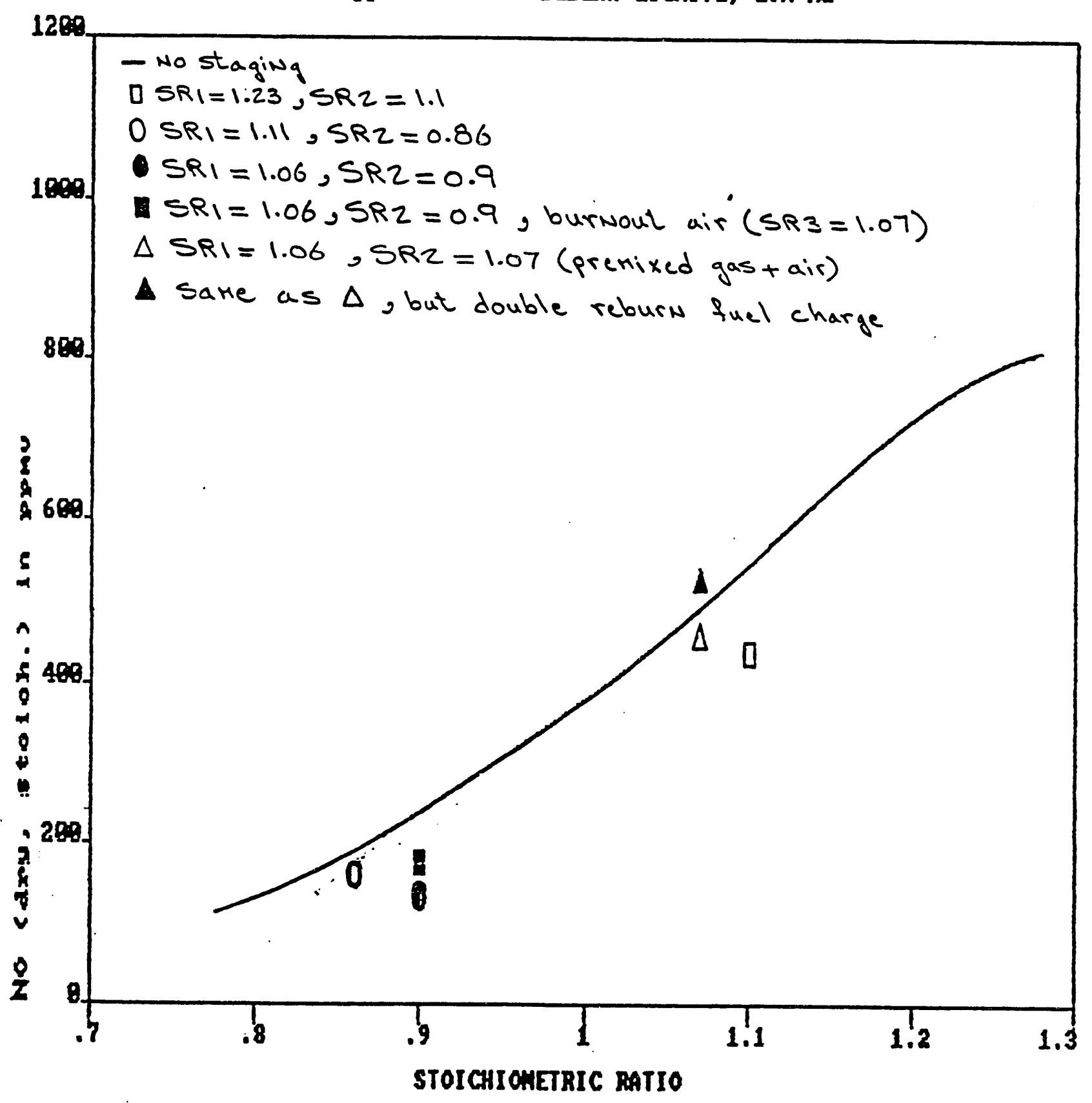

Figure 6. 
HO in PPW U5. SRI/ UTAH BITUMINOUS

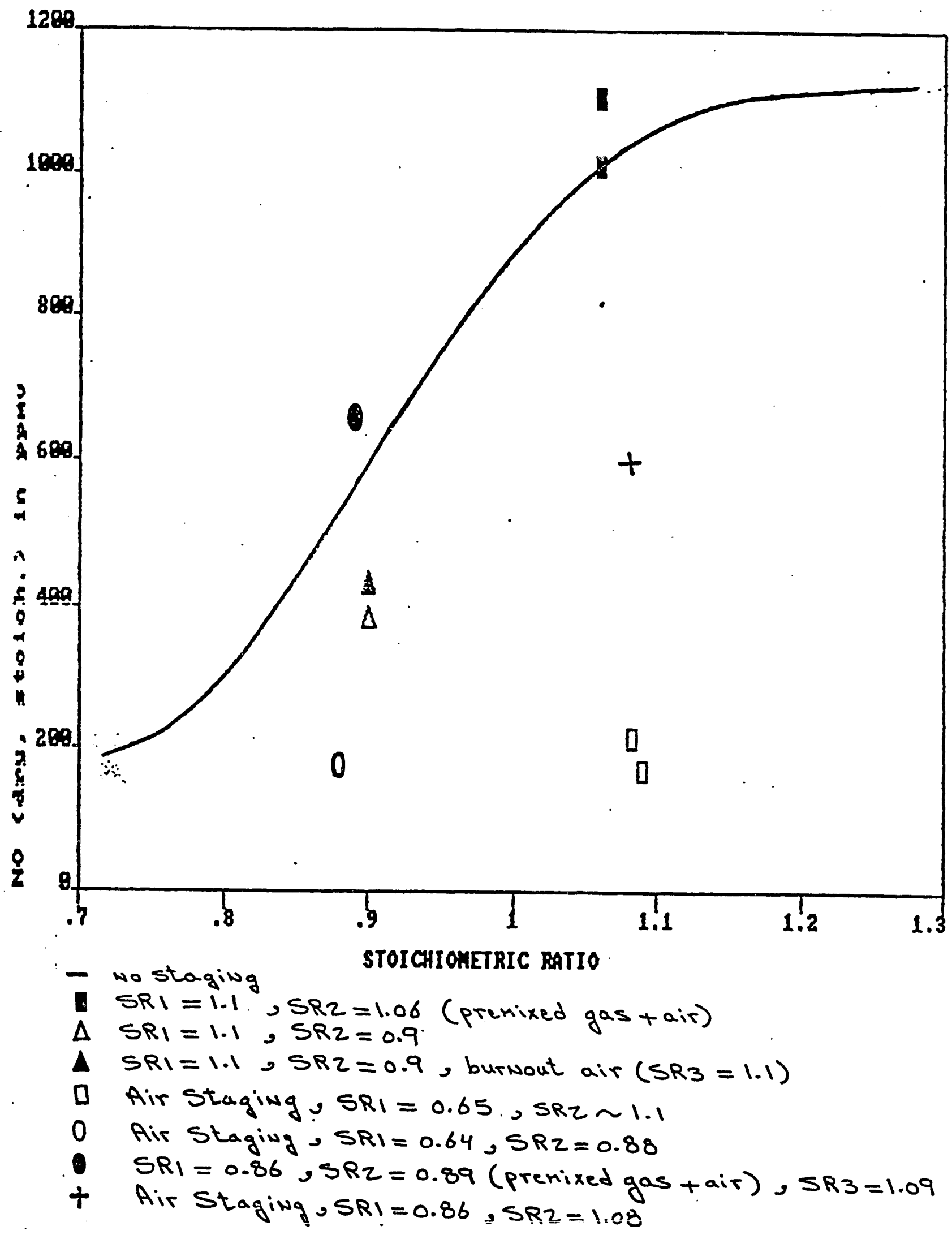

Figure 7. 
nudd $M !\left(H D ! O 1 S^{\circ}\right.$ hHO) OZN

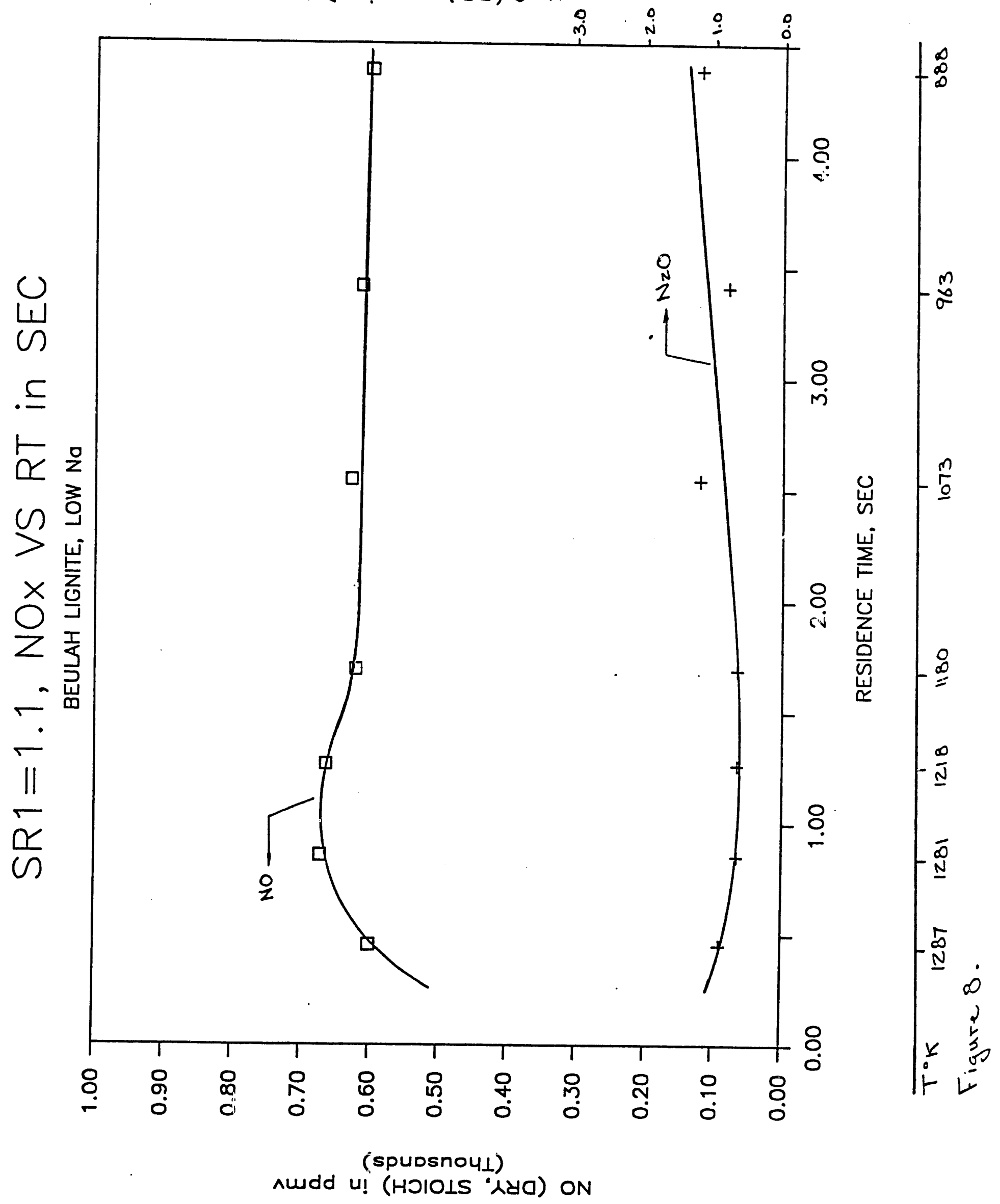




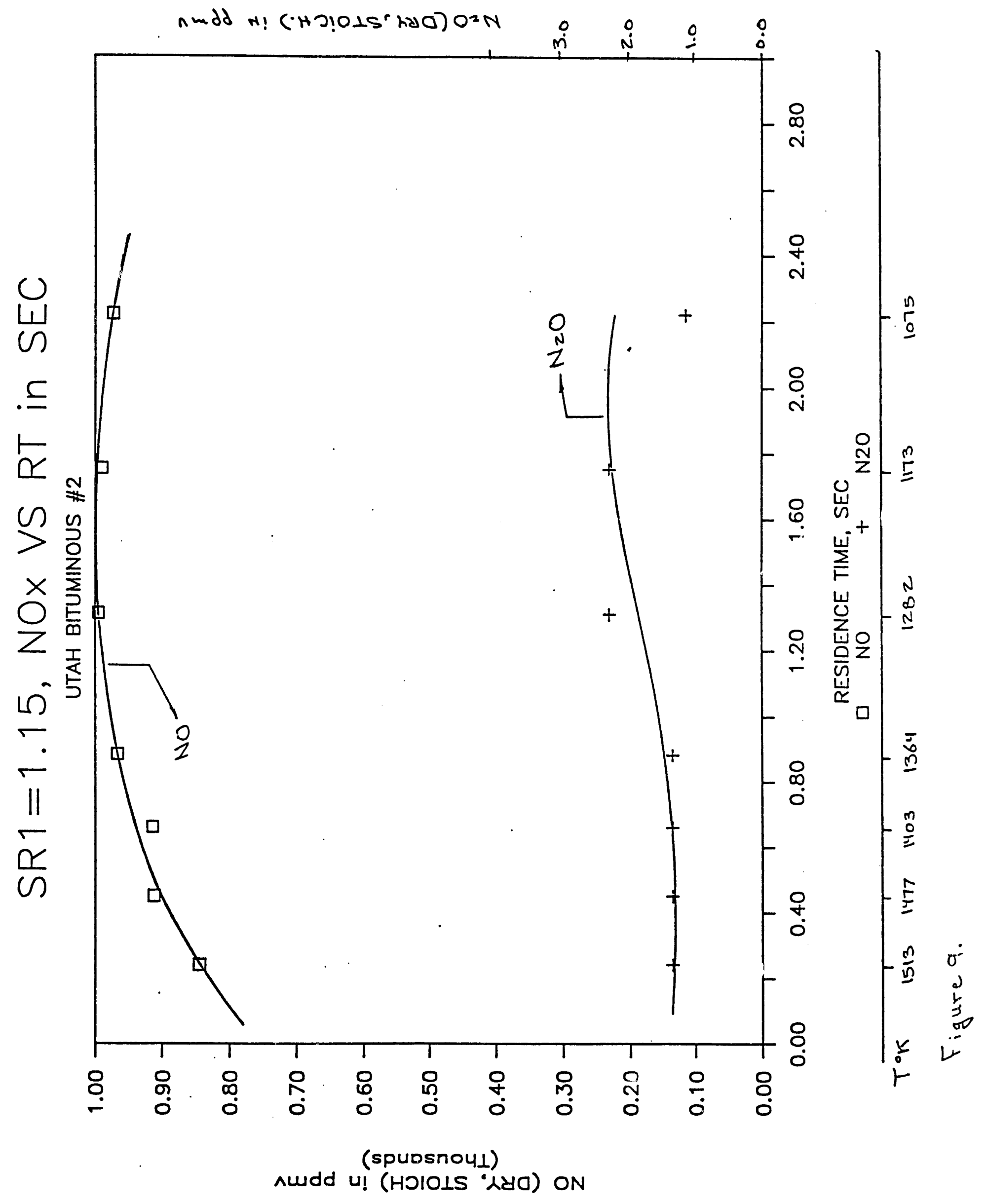




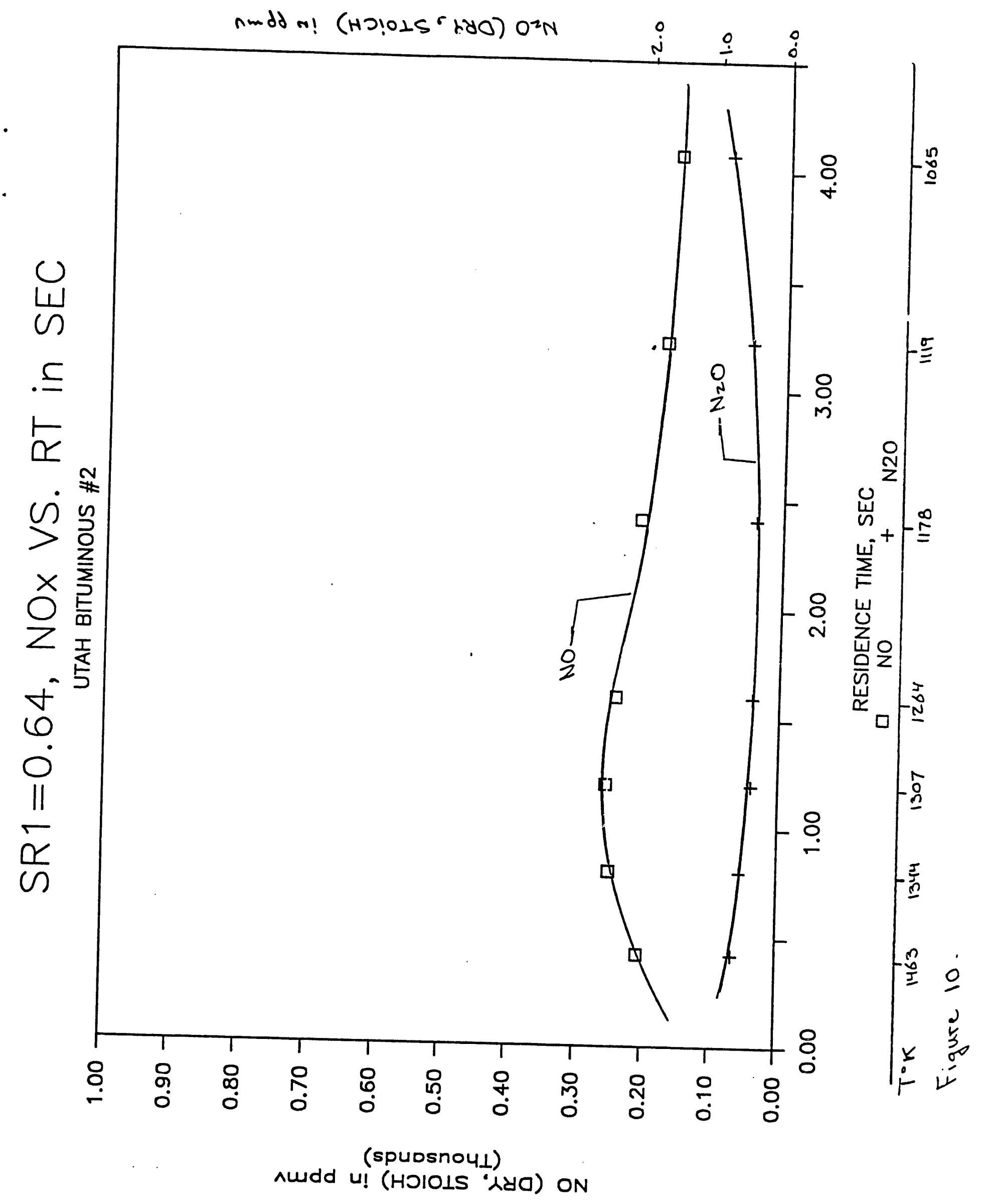




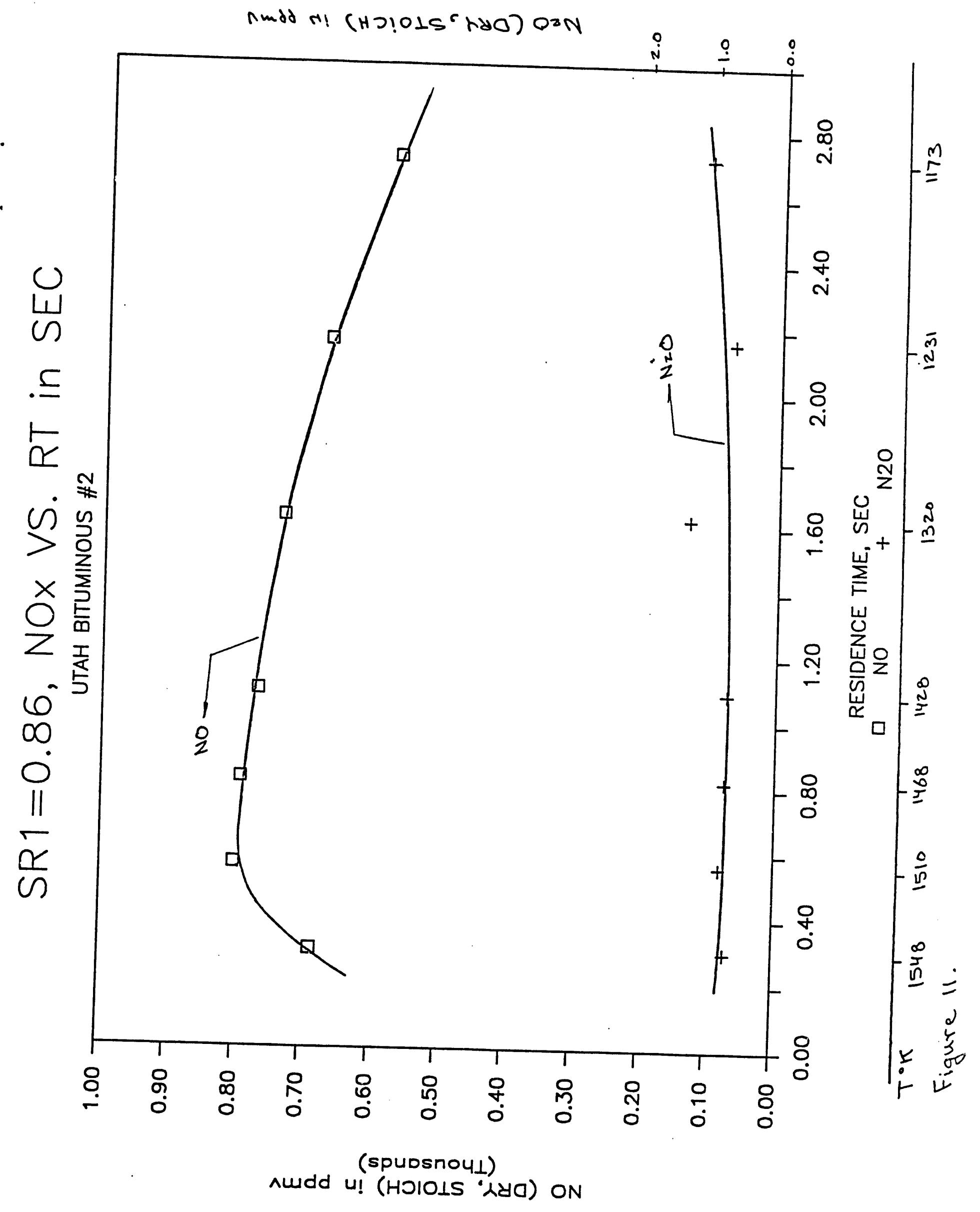




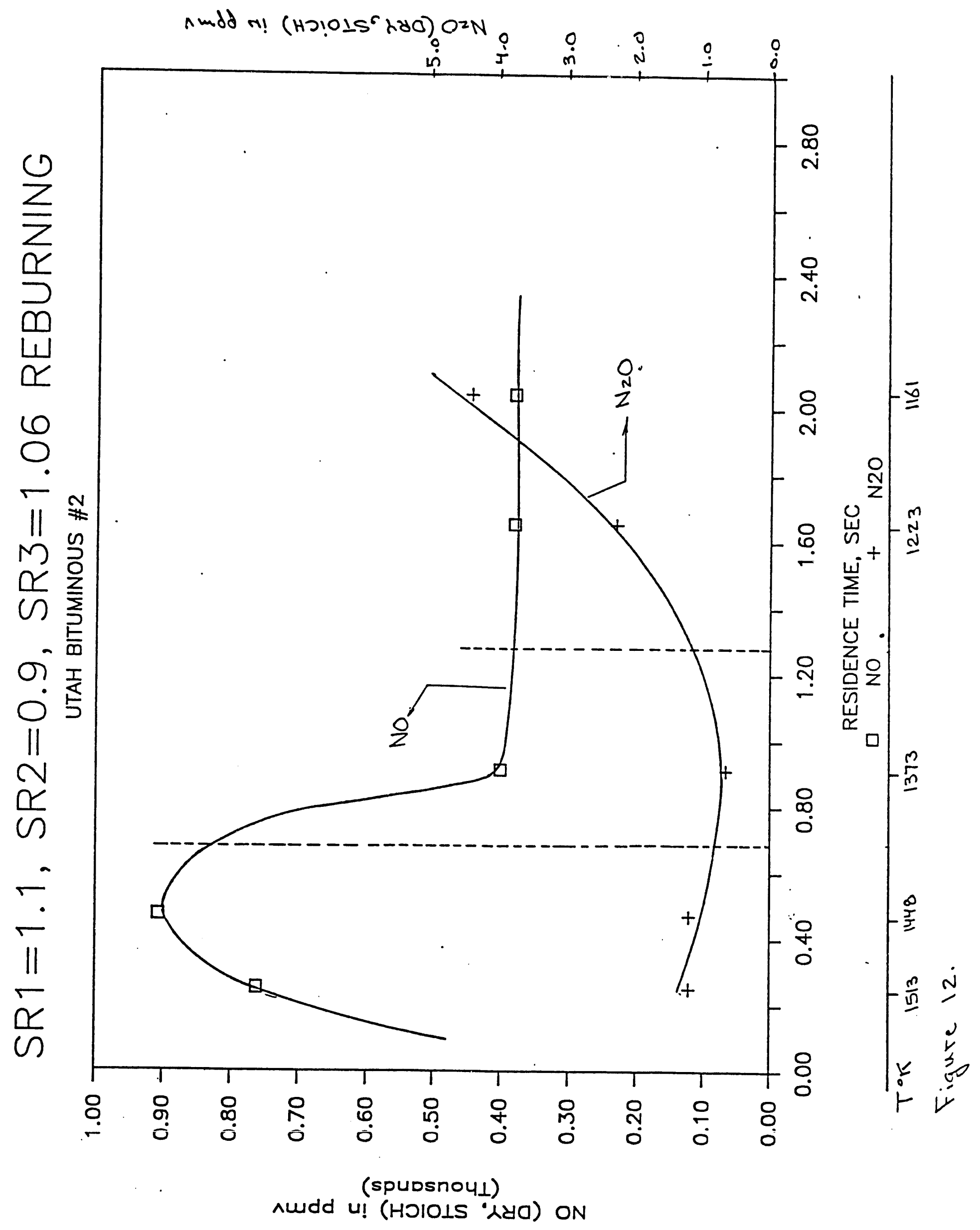




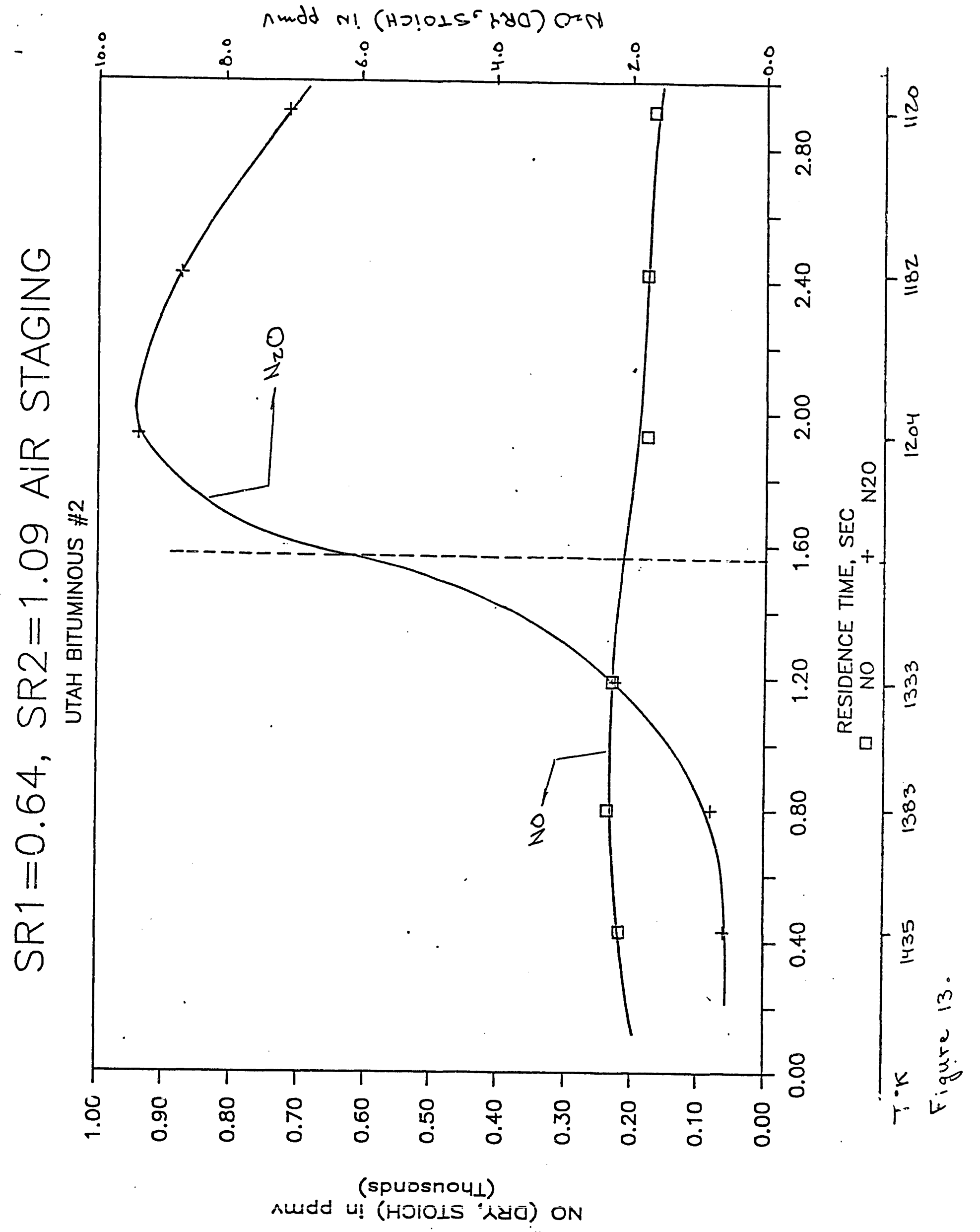




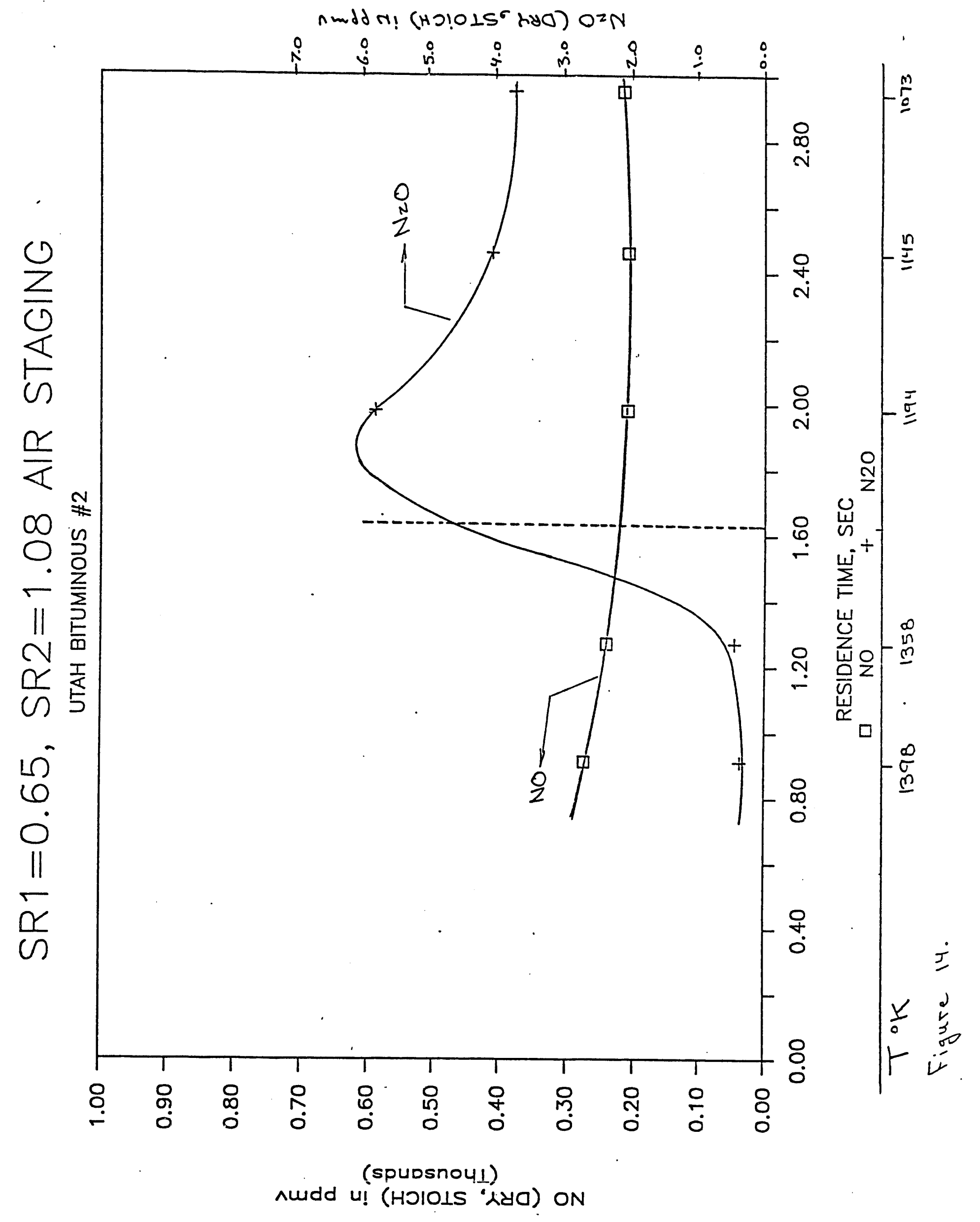


nudd $\mathrm{NI}$ (HDIOLS ROO) OIN

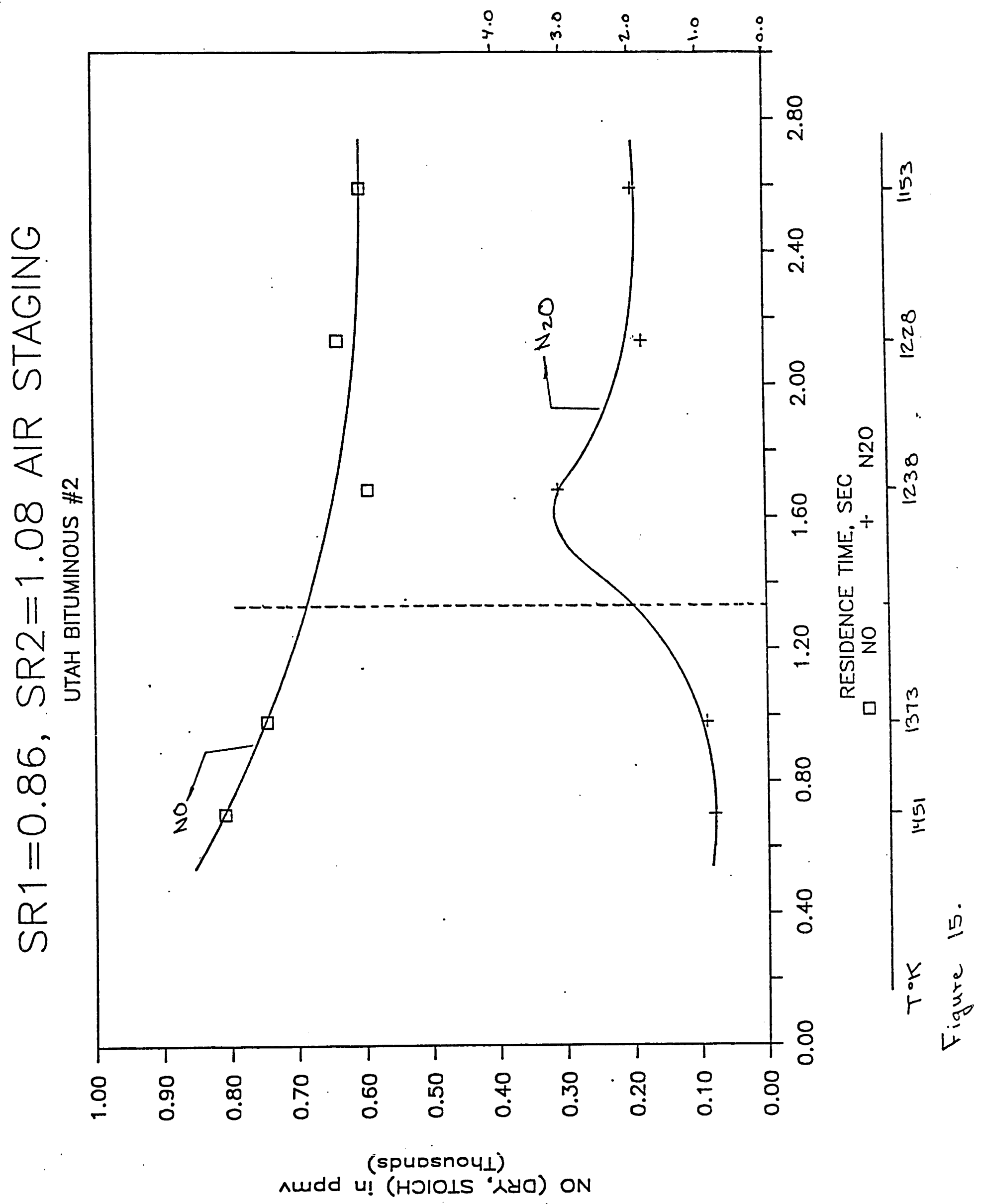




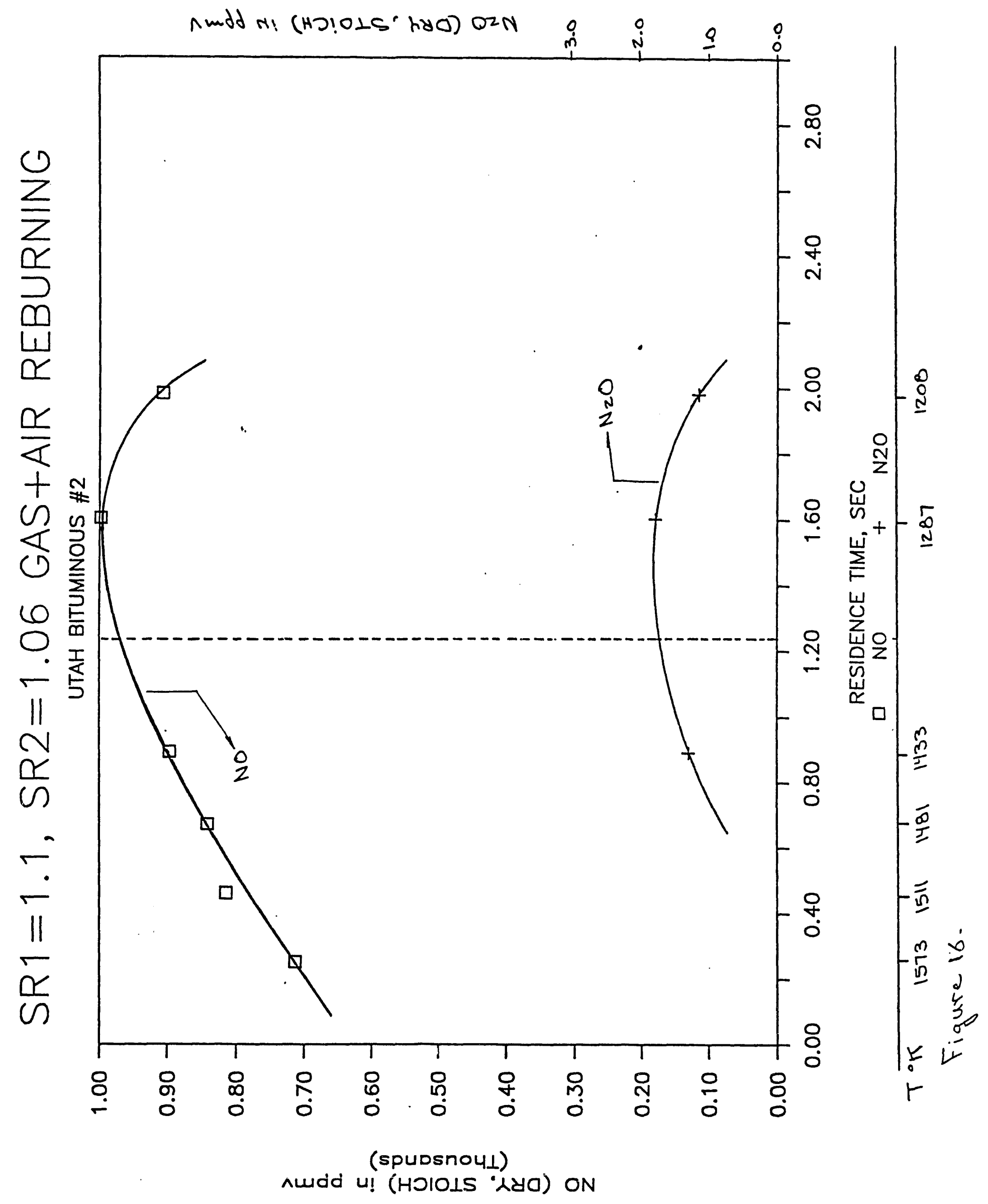




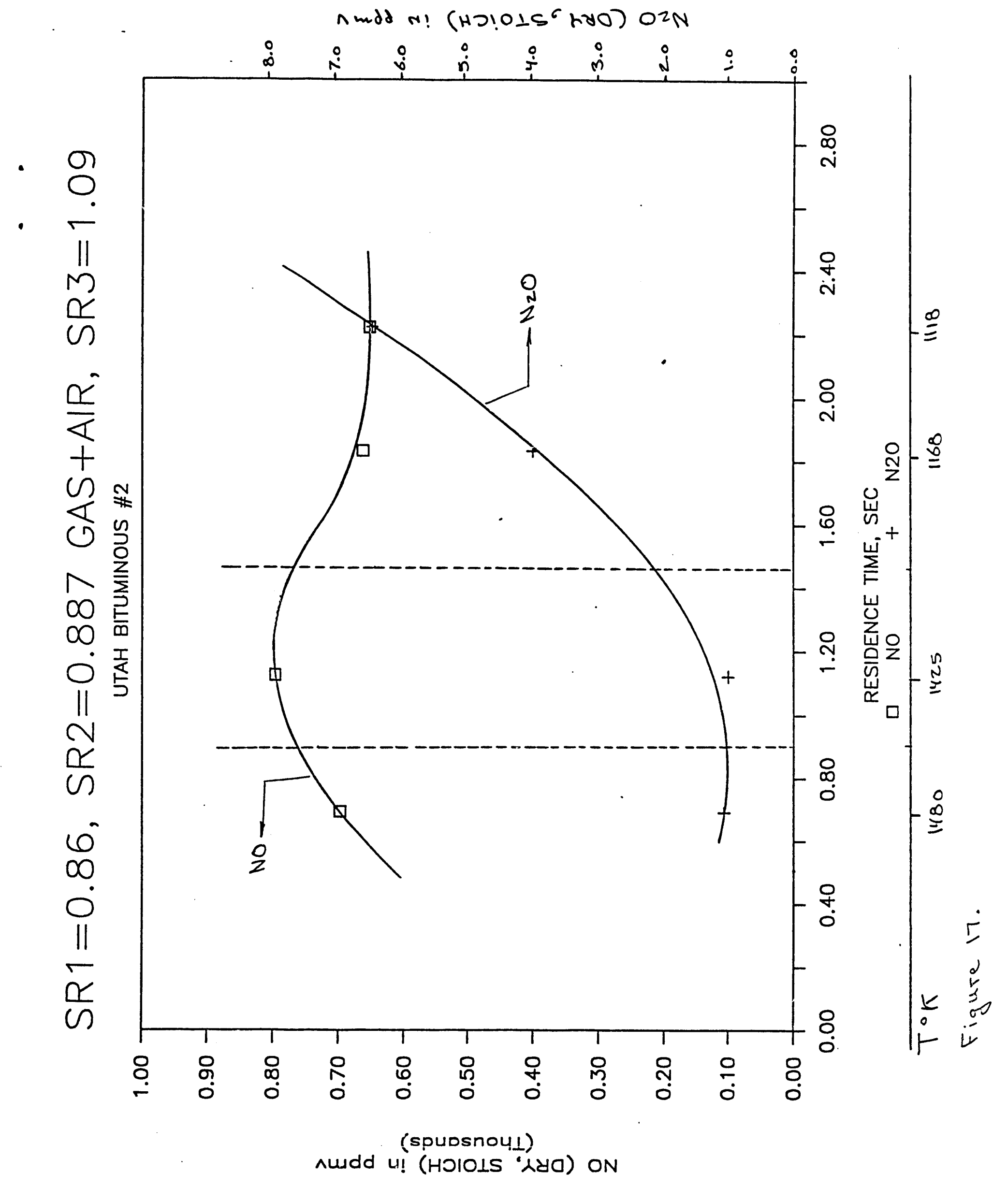


nudd N! (HJiOLer hyO) D.N

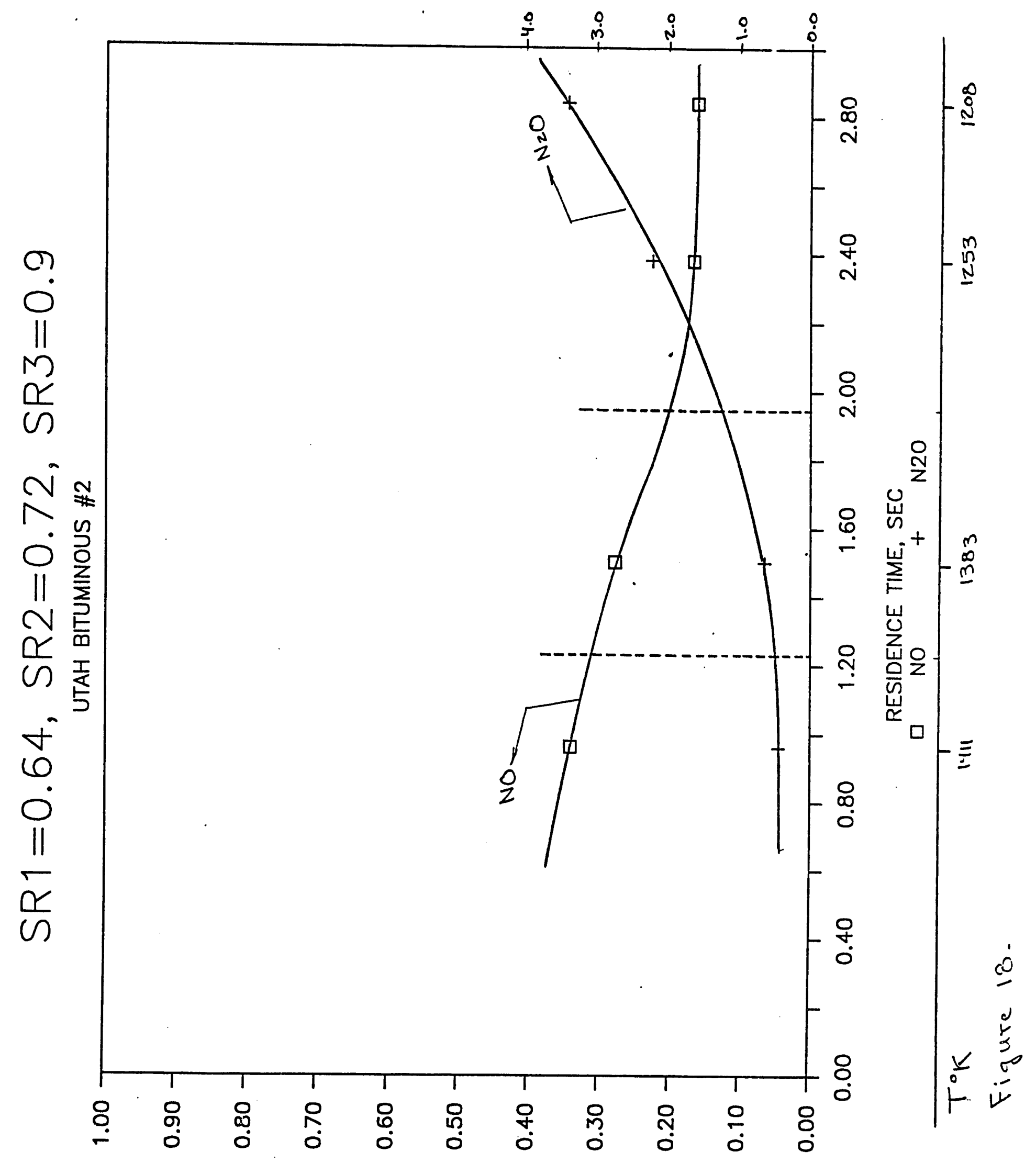

(spudsnoul)

Audd U! (HOIOLS iva) ON 
